\title{
REVIEW
}

\section{Induced pluripotent stem cell-derived cardiomyocytes for cardiovascular disease modeling and drug screening}

\author{
Arun Sharma ${ }^{1,2}$, Joseph C Wu $u^{2,3,4}$ and Sean M Wu $u^{2,3^{*}}$
}

\begin{abstract}
Human induced pluripotent stem cells (hiPSCs) have emerged as a novel tool for drug discovery and therapy in cardiovascular medicine. hiPSCs are functionally similar to human embryonic stem cells (hESCs) and can be derived autologously without the ethical challenges associated with hESCs. Given the limited regenerative capacity of the human heart following myocardial injury, cardiomyocytes derived from hiPSCs (hiPSC-CMs) have garnered significant attention from basic and translational scientists as a promising cell source for replacement therapy. However, ongoing issues such as cell immaturity, scale of production, inter-line variability, and cell purity will need to be resolved before human clinical trials can begin. Meanwhile, the use of hiPSCs to explore cellular mechanisms of cardiovascular diseases in vitro has proven to be extremely valuable. For example, hiPSC-CMs have been shown to recapitulate disease phenotypes from patients with monogenic cardiovascular disorders. Furthermore, patient-derived hiPSC-CMs are now providing new insights regarding drug efficacy and toxicity. This review will highlight recent advances in utilizing hiPSC-CMs for cardiac disease modeling in vitro and as a platform for drug validation. The advantages and disadvantages of using hiPSC-CMs for drug screening purposes will be explored as well.
\end{abstract}

\footnotetext{
* Correspondence: smwu@stanford.edu

${ }^{2}$ Cardiovascular Institute, Stanford University School of Medicine, Stanford, CA 94305, USA

${ }^{3}$ Division of Cardiovascular Medicine, Department of Medicine, Stanford University School of Medicine, Stanford, CA 94305, USA
}

Full list of author information is available at the end of the article

\section{Introduction}

The discovery of induced pluripotent stem cells (iPSCs) by Shinya Yamanaka and Kazutoshi Takahashi in 2006 revolutionized the field of stem cell biology [1]. For the first time, pluripotent stem cells could be obtained not only from the inner cell mass of the blastocyst-stage embryo but also from reprogramming somatic adult tissue by enforced expression of Oct4, Klf4, Sox2, and c-Myc (OKSM). While the potential applications for human iPSCs are largely similar to those for human embryonic stem cells (hESCs; that is, derivation of a specific human cell type of interest from a self-renewing source), the ethically complex hurdles involving the use of discarded human embryos could now be avoided.

The initial success with derivation of iPSCs from mouse tail tip fibroblasts has been replicated by laboratories around the world using adult skin, blood, hair follicle, and even epithelial cells from urine samples [2-4]. Initially, retroviral vectors were used to introduce OKSM into somatic cells in order to generate iPSCs [1]. However, concerns of viral integration-mediated oncogenesis spurred a number of advancements in reprogramming technologies, including the development of non-integrating, and even non-viral methods of iPSC generation $[5,6]$. In less than a decade, we have witnessed the development of a biomedical industry focusing on improving the technology of iPSC generation as well as their downstream applications [7]. Major academic and private research institutions have created iPSC 'cores' focused on efficient, high quality, and disease-specific iPSC production as well as services such as consulting and education for investigators interested in practical knowledge involving iPSC maintenance and applications. In all, the rapid progress made in this field has now enabled the entire iPSC production process from somatic cell harvesting to iPSC generation to isolation of differentiated cell types such as neurons, blood cells, and cardiomyocytes to take as little as a month or 
less [8-10]. Indeed, few scientific discoveries have had such a meteoric rise to prominence as iPSC technology. In recognition of the great promise of this field, Yamanaka was awarded the 2012 Nobel Prize in Physiology and Medicine, a mere 6 years after the initial discovery.

This review article will discuss recent advances in iPSC technology and its potential applications in cardiovascular medicine, namely cell-based therapy, disease modeling, and drug discovery (Figure 1). An emphasis will be placed on derivation of cardiomyocytes from iPSCs for in vitro disease modeling and drug screening studies.

\section{Significance of heart disease in the western world}

Heart disease remains the most common cause of morbidity and mortality in the western world [11]. An estimated $\$ 300$ billion is spent each year on managing cardiovascular disease in the US [11]. Each year over 700,000 people are diagnosed with myocardial infarction and develop an increased risk of a second myocardial infarction later in life [11]. Since the mammalian adult heart cannot fully replace its lost cardiomyocytes through proliferation of surviving cardiomyocytes, its capacity for regeneration is quite limited [12]. Using ${ }^{14} \mathrm{C}$ radioisotope dating, a recent study showed that the juvenile human heart can replace 1 to $2 \%$ or less of its cardiomyocytes per year, and this capacity declines with age [13]. Hence, the human heart is especially vulnerable to injury. Furthermore, a poorly conductive fibrotic scar replaces the lost cardiomyocytes [14]. This scar tissue is unable to effectively propagate the cardiac action potential and makes the heart vulnerable to developing ventricular arrhythmia [15].

\section{The promises and pitfalls of human iPSC-derived cardiomyocytes for cell replacement therapy}

As the human heart is largely unable to replenish lost cardiomyocytes, studies have been conducted to examine ways to restore cardiac function by replacing these cardiomyocytes. Strategies thus far have included: 1) coaxing existing cardiomyocytes to divide, 2) stimulating the expansion and differentiation of existing cardiac stem/ progenitor cells, or 3) transplantation of autologous or pluripotent stem cell-derived cells. These strategies have achieved mixed results. Multiple groups have demonstrated the ability to enhance cardiomyocyte division in animal models by manipulating growth factors and cell cycle regulators such as YAP1 and Neuregulin1 without inducing cardiac tumors [16,17]. Alternatively, isolation and re-transplantation of endogenous cardiac stem/progenitor populations have been explored in detail in recent years. While the human heart exhibits a very limited capacity for endogenous regeneration, this small amount of cardiomyocyte turnover may be due to differentiation of resident cardiac stem cells, which occurs at

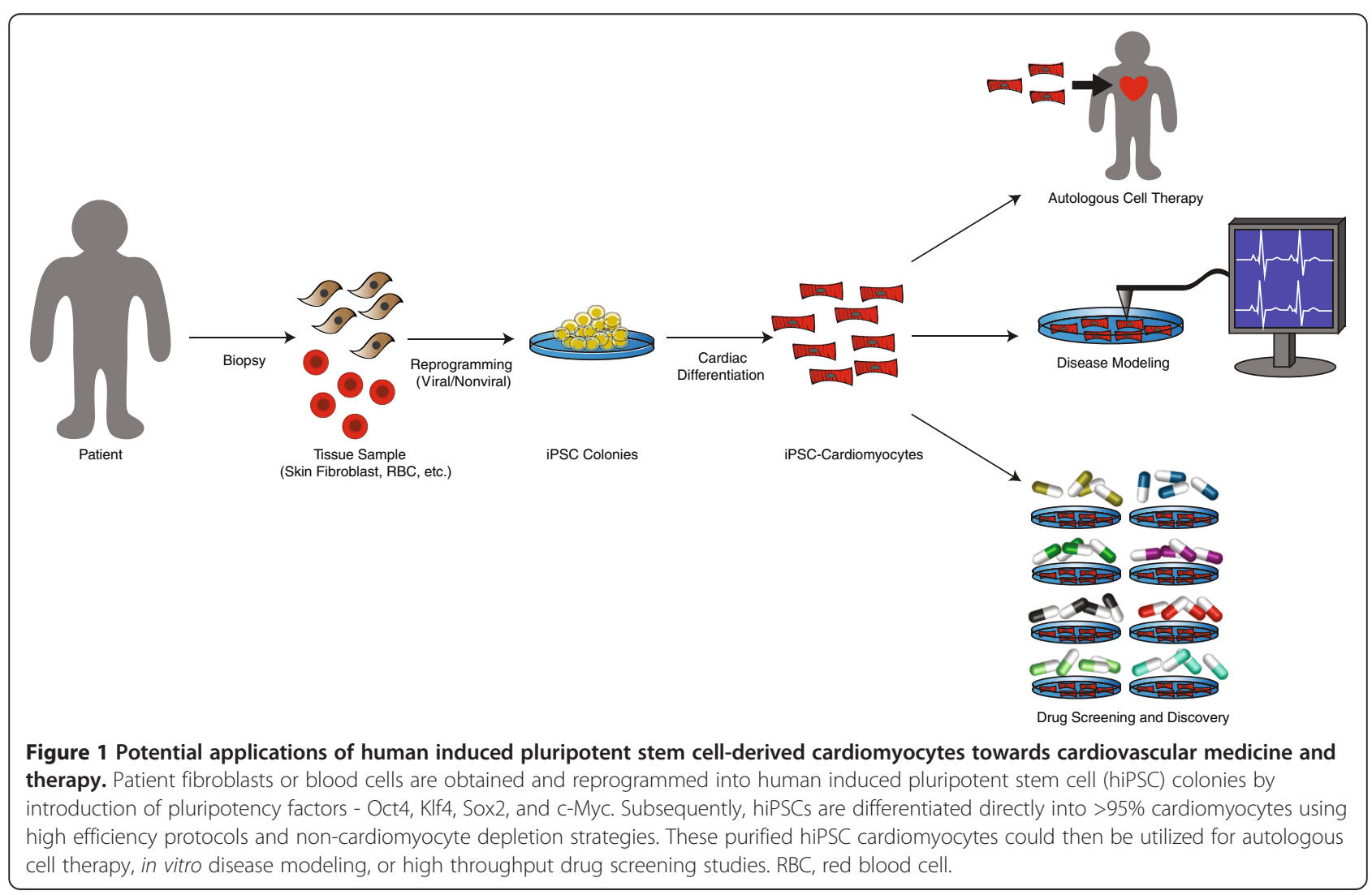


an extremely low rate [18]. These rare cells have been investigated as a potential cell source to replace lost cardiomyocytes [18].

Pluripotent stem cells have also been explored as a promising cell source for cardiac cell therapy. For more than a decade, researchers have been able to derive cardiomyocytes from ESCs (ESC-CMs) that are phenotypically similar to adult cardiomyocytes [19]. Recently, investigators have manipulated the same growth factors that are thought to promote cardiogenesis in vivo, such as the activin, bone morphogenetic protein, and Wnt signaling pathways, to efficiently derive ESC-CMs in large quantities [20]. Previous studies have shown that ESC-CMs are able to successfully integrate into the injured mouse heart and improve cardiac function $[21,22]$. While ESC differentiation allows for the production of a virtually unlimited pool of cardiomyocytes, significant biological obstacles, such as cell immunogenicity, survival, and electrophysiological integration, remain to be addressed prior to their application in human clinical trials. Given that ESCs are derived from the inner cell mass of early stage human embryos, political and ethical hurdles, in addition to the aforementioned biological obstacles, have played a role in preventing hESCs from being actively studied as a source of cells for therapy. In this regard, human iPSCs (hiPSCs) should hold a significant advantage over hESCs because hiPSCs are derived from somatic cells of the patient and contain the patient's own genetic material. They may be considered as autologous cells that are immunologically compatible, although some studies have demonstrated otherwise [23,24]. This remains a contentious topic and more work is needed to clarify this issue as more recent publications have argued that ESCs, iPSCs, and their derivatives show negligible immunogenicity following transplantation $[25,26]$. Similar to hESCs, the differentiation of hiPSCs towards cardiomyocytes can be achieved using a number of high-efficiency protocols, whereby greater than $95 \%$ of the differentiated hiPSCs become cardiomyocytes from their initial hiPSC population [27]. These iPSC-derived cardiomyocytes (iPSC-CMs) exhibit features of bona fide cardiomyocytes, including sarcomeric striation and spontaneous action potential $[28,29]$. However, concerns remain regarding their immaturity and lack of functional and electrophysiological fidelity in comparison to adult cardiomyocytes.

\section{Practical considerations in the use of hiPSC-CMs for disease modeling and cell therapy}

Despite the advantages that hiPSCs have over hESCs and other cell types as the source of transplantable cells, a number of critical issues with hiPSC-CM technology remain to be addressed. As mentioned above, the phenotypic immaturity of hiPSC-CMs is most concerning.
hiPSC-CMs largely resemble fetal cardiomyocytes in terms of ion channel structure and sarcomeric morphology [30,31]. Notably, hiPSC-CMs do not form organized Ttubules, which comprise a network of intracellular structures involved in cardiomyocyte action potential propagation and calcium influx [32]. Additionally, there is significant heterogeneity in the subtypes of hiPSC-CMs, including atrial, nodal, and ventricular cardiomyocytes, that can be found with each batch of differentiation [33]. The myosin light chain proteins MLC2A and MLC2V can be used to distinguish between atrial and ventricular cardiomyocytes in mice, and MLC2V has been used to genetically select for ventricular myocytes using a lentivirus-transduced hESC line [34-36]. However, there is no highly reliable cell surface marker that would allow for fluorescence activated cell sorting of these hiPSC-CM sub-populations. The use of SIRPA (Signal-regulatory protein alpha) as the surface marker for hESC-CM and hiPSC-CM purification has proven to be variably efficient [37]. Thus, obtaining a pure population of hiPSC-CMs remains challenging.

With regards to the efficiency of cardiac differentiation, significant line-to-line and patient-to-patient variability exists. While differentiation protocols have improved dramatically over the last few years, we and others have noticed that cardiac differentiation protocols also produce other mesodermal derivatives, such as smooth muscle cells and endothelial cells [38]. Some hiPSCs remain undifferentiated even after days of small molecule treatment [10]. For the purpose of cell therapy, the presence of undifferentiated cells presents a significant concern because of the potential for teratoma formation [39]. Furthermore, the production of hiPSCs from a patient-specific tissue sample and the subsequent cardiac differentiation process can take weeks, which may be a significant barrier to success if it turns out that cell transplantation as a therapeutic intervention for acute myocardial injury has to be given within a month or less.

Finally, the economic barrier to personalized hiPSCderived cell therapy is considerable given that thousands of dollars are needed to generate a set of hiPSC lines for each patient and ten times that are needed to generate sufficient (approximately 1 billion or more) cardiomyocytes for each treatment. It is possible that the use of a genetically and immunologically (that is, human leukocyte antigen haplotype) defined set of hiPSC lines to generate 'off the shelf' hiPSC-CMs for a population of patients may be more practical and economically feasible, although these hiPSC-CMs are likely to encounter immune response that require long-term immunosuppression, which introduces additional costs and potential infectious complications that may approximate, if not exceed, the cost of autologous hiPSC-CM therapy in the long run. 
Table 1 Examples of currently published human induced pluripotent stem cell-derived cardiomyocyte disease models

\begin{tabular}{|c|c|c|c|c|}
\hline $\begin{array}{l}\text { Cardiovascular } \\
\text { disease category }\end{array}$ & $\begin{array}{l}\text { Cardiovascular } \\
\text { disease modeled } \\
\text { with hiPSC-CMs }\end{array}$ & Phenotype observed/recapitulated in vitro & $\begin{array}{l}\text { Drug treatment } \\
\text { to rescue } \\
\text { phenotypes }\end{array}$ & Reference \\
\hline Cell signaling defect & LEOPARD syndrome & $\begin{array}{l}\text { Cardiomyocyte hypertrophy, NFATC } 4 \text { nuclear accumulation, } \\
\text { increase in RAS/MAPK phosphorylation }\end{array}$ & NA & {$[28]$} \\
\hline Channelopathy & Long QT syndrome 1 & Drug-induced prolongation of field potential duration & NA & [40] \\
\hline Channelopathy & Long QT syndrome 1 & $\begin{array}{l}\text { Cardiac action potential prolongation, irregularities in potassium- } \\
\text { gated voltage channel (KCNQ1) localization }\end{array}$ & Propranolol & [33] \\
\hline Channelopathy & Long QT syndrome 2 & Cardiac action potential prolongation & $\begin{array}{l}\text { Pinacidil, nifedipine, } \\
\text { ranolazine }\end{array}$ & [41] \\
\hline Channelopathy & Long QT syndrome 2 & $\begin{array}{l}\text { Prolonged field and action potential, drug-induced early after } \\
\text { depolarizations }\end{array}$ & $\begin{array}{l}\text { Nicorandil, nadolol, } \\
\text { propranolol }\end{array}$ & {$[42]$} \\
\hline Channelopathy & Long QT syndrome 2 & $\begin{array}{l}\text { Prolonged action potential duration, increased sensitivity to } \\
\text { arrhythmogenic drugs }\end{array}$ & NA & [43] \\
\hline Channelopathy & Long QT syndrome 3 & $\begin{array}{l}\text { Prolonged action potential duration, early after depolarization, } \\
\text { sodium current irregularities }\end{array}$ & NA & [44] \\
\hline Channelopathy & Long QT syndrome 3 & Sodium current irregularities, longer action potential duration & NA & [45] \\
\hline Channelopathy & Long QT syndrome 3 & Sodium current irregularities, prolonged QT interval & NA & [46] \\
\hline Channelopathy & $\begin{array}{l}\text { Long QT syndrome } 8 \text {, } \\
\text { Timothy syndrome }\end{array}$ & $\begin{array}{l}\text { Anomalous calcium transients, cardiac action potential } \\
\text { prolongation, irregular cardiomyocyte contraction }\end{array}$ & Roscovitine & [47] \\
\hline Channelopathy & CPVT-1 & $\begin{array}{l}\text { Intracellular calcium concentration irregularities, delayed after } \\
\text { depolarizations }\end{array}$ & Dantrolene & [48] \\
\hline Channelopathy & CPVT-1 & $\begin{array}{l}\text { Abnormal calcium release, abnormal calcium response after } \\
\text { phosphorylation, anomalous calcium transients }\end{array}$ & NA & [49] \\
\hline Channelopathy & CPVT-1 & $\begin{array}{l}\text { Abnormal calcium transients, early after depolarizations, reduced } \\
\text { sarcoplasmic reticulum calcium concentration }\end{array}$ & NA & {$[50]$} \\
\hline Channelopathy & CPVT-1 & $\begin{array}{l}\text { Delayed after depolarizations, calcium transient irregularities, } \\
\text { abnormal calcium concentrations }\end{array}$ & $\begin{array}{l}\text { Flecainide, } \\
\text { thapsigargin }\end{array}$ & [51] \\
\hline $\begin{array}{l}\text { Cardiomyopathy } \\
\text { caused by structural/ } \\
\text { sarcomeric protein } \\
\text { mutation }\end{array}$ & CPVT-2 & $\begin{array}{l}\text { Isoproterenol-induced delayed after depolarizations, abnormal } \\
\text { calcium concentrations, myofibril disorganization, sarcoplasmic } \\
\text { reticulum abnormalities }\end{array}$ & NA & {$[32]$} \\
\hline $\begin{array}{l}\text { Cardiomyopathy } \\
\text { caused by structural/ } \\
\text { sarcomeric protein } \\
\text { mutation }\end{array}$ & $\begin{array}{l}\text { Familial dilated } \\
\text { cardiomyopathy }\end{array}$ & $\begin{array}{l}\text { Reduced force output during cardiomyocyte contraction, } \\
\text { sarcomeric structural irregularities, abnormal beating rate, } \\
\text { abnormal calcium transients }\end{array}$ & Metoprolol & {$[52]$} \\
\hline $\begin{array}{l}\text { Cardiomyopathy } \\
\text { caused by structural/ } \\
\text { sarcomeric protein } \\
\text { mutation }\end{array}$ & $\begin{array}{l}\text { Familial hypertrophic } \\
\text { cardiomyopathy }\end{array}$ & $\begin{array}{l}\text { Enlarged hiPSC-CM phenotype, elevated intracellular calcium } \\
\text { levels, irregular calcium transients }\end{array}$ & Verapamil & [53] \\
\hline $\begin{array}{l}\text { Cardiomyopathy } \\
\text { caused by structural/ } \\
\text { sarcomeric protein } \\
\text { mutation }\end{array}$ & ARVD/C & $\begin{array}{l}\text { Reduced expression of plakophilin-2, increase in intracellular lipid } \\
\text { levels, disorganized hiPSC-CM sarcomeric structure }\end{array}$ & $\begin{array}{l}\text { Nifedipine, } \\
\text { isoproterenol }\end{array}$ & [54] \\
\hline $\begin{array}{l}\text { Cardiomyopathy } \\
\text { caused by structural/ } \\
\text { sarcomeric protein } \\
\text { mutation }\end{array}$ & ARVD/C & $\begin{array}{l}\text { Irregular plakophilin-2 nuclear accumulation, diminished } \beta \text {-catenin } \\
\text { activity in cardiogenic conditions, abnormal peroxisome proliferator- } \\
\text { activated receptor gamma activation, calcium handling defects }\end{array}$ & NA & {$[55]$} \\
\hline $\begin{array}{l}\text { Cardiomyopathy } \\
\text { caused by structural/ } \\
\text { sarcomeric protein } \\
\text { mutation }\end{array}$ & Pompe disease & $\begin{array}{l}\text { High glycogen levels, ultrastructural abnormalities, cellular } \\
\text { respiration irregularities }\end{array}$ & $\begin{array}{l}\text { I-carnitine, acid } \\
\text { alpha-glucosidase }\end{array}$ & {$[56]$} \\
\hline
\end{tabular}


These issues, while beyond the scope of this review article, are extremely important and well deserving of research efforts from health policy experts in the government and private sector. Given these and other concerns, it is no surprise that cell therapy clinical trials using hiPSC-CMs have not been undertaken thus far.

\section{hiPSC-CMs for in vitro disease modeling and drug discovery}

While the use of hiPSC-CMs for in vivo cell therapy may be feasible in the future, the use of hiPSC-CMs for in vitro disease modeling and drug screening has been demonstrated recently (Table 1). Cardiovascular disease with a monogenic origin and cell-autonomous phenotype may be recapitulated 'in the dish' using hiPSC technology. For example, hiPSC-CMs have been used to study cardiac disorders caused by misregulated intracellular signaling pathways such as in LEOPARD syndrome [28]. LEOPARD syndrome is due to gene mutations that result in hyperactivity of the RAS/mitogen-activated protein kinase (MAPK) signaling pathway controlling multiple cellular processes such as migration, proliferation, growth, and death [66]. LEOPARD syndrome hiPSCs carrying a point mutation in the PTPN11 gene, which encodes a tyrosine-protein phosphatase downstream of RAS signaling, have been reported [28]. Analogous to the hypertrophic cardiomyopathy phenotype in LEOPARD syndrome patients, hiPSC-CMs from these patients exhibit larger size than wild-type hiPSC-CMs. In addition, hiPSC-CMs from LEOPARD syndrome patients had abnormal accumulation of NFAT (nuclear factor of activated $\mathrm{T}$ cells), suggesting a role for this pathway in the onset of LEOPARD syndrome. LEOPARD syndrome hiPSCs and hiPSC-CMs also exhibited a significant increase in phosphorylation of multiple components of the RAS/MAPK signaling pathway, confirming the contribution of this pathway to disease onset. It should be noted, however, that this and the majority of iPSC disease modeling studies have focused on monogenic diseases and usually from those with point mutations in the coding regions of genes, since these diseases hold the strongest genotype-phenotype correlation (Table 1). Future studies are likely to focus on polygenic cardiovascular diseases and diseases that are environmentally influenced since these diseases account for a significant proportion of morbidity and mortality in developed countries [67].

\section{Modeling channelopathies with hiPSC-CMs}

'Channelopathies', or diseases of ion channel mutations, result from mutations in the coding regions of ion channels causing misregulated cellular action potential [57]. One such disease is long QT syndrome, a hereditary disorder characterized by a delay in the repolarization of the myocardium that manifests as prolongation of the
QT interval in an electrocardiogram [33,41,42,47]. The patients in these studies had mutations in genes such as $K C N Q 1, S C N 5 A$, and $K C N H 2$, which encode sodium and potassium channels essential for correctly initiating and propagating the cardiac action potential. In one study, hiPSC-CMs generated by Moretti and colleagues showed prolongation in action potential similar to the QT prolongation seen in long QT patients from which hiPSCs were initially derived [33]. Morphologically, hiPSC-CMs from these patients exhibit irregularities in the subcellular localization of the potassium gated voltage channel encoded by KCNQ1. Treatment with propranolol, a beta-adrenergic blocker, abrogated the increase in action potential duration caused by the beta agonist isoproterenol. Similarly, Itzhaki and colleagues showed the recapitulation of the QT prolongation phenotype exhibited by patients with long QT syndrome 2 caused by a mutation in $\mathrm{KCNH} 2$ [41]. These authors were able to restore the proper action potential duration in hiPSC-CMs using pinacidil and nifedipine, a potassium channel regulator and a calcium channel blocker, respectively. Likewise, Yazawa and colleagues created hiPSC-CMs recapitulating the prolonged action potential phenotype from patients with a point mutation in Cav1.2, the A1 subunit for the L-type voltage-dependent calcium channel, causing long QT syndrome 8 [47]. This mutation is associated with Timothy syndrome, a disorder characterized by mental retardation, ventricular arrhythmia, and external physical abnormalities [58]. In vitro treatment with roscovitine, a compound that prolongs the deactivation of the voltage-dependent calcium channel that is misregulated in Timothy syndrome, corrected the anomalous calcium transients associated with this disease [47].

Finally, several studies have created patient-specific hiPSC lines from individuals with inherited catecholaminergic polymorphic ventricular tachycardia (CPVT-1) [48-51]. This disorder, characterized by stress-induced ventricular arrhythmia, is caused by a point mutation in the ryanodine receptor 2 (RYR2) [59]. This receptor, found on the cardiomyocyte sarcoplasmic reticulum, is responsible for proper calcium-mediated release of intracellular calcium in cardiomyocytes, and thus critically regulates cardiomyocyte excitation-contraction coupling [59]. Several drugs, such as flecainide, thapsigargin, and dantrolene, were used in these studies to restore intracellular ion concentration to normal levels [48-51]. Thus, it appears that hiPSC-CMs can effectively recapitulate the disease phenotype associated with channelopathies.

\section{Modeling sarcomeric and adhesion protein mutation cardiomyopathy with hiPSCs}

We and others have recently published studies describing the in vitro cellular phenotype from hiPSC-CMs 
generated from patients with dilated and hypertrophic cardiomyopathy. These diseases are best characterized genetically by their known mutations in sarcomeric proteins. From a patient family cohort with affected individuals harboring a mutation in the TNNT2 gene, we generated hiPSC-CMs and showed that these cells exhibit irregular sarcomeric organization and abnormal force generation and beating rate [52]. These phenotypes are representative of the in vivo phenotype in patients with mutated TNNT2 causing dilated cardiomyopathy, the most common cause of heart failure following hypertension and coronary artery disease and the most common indication for heart transplantation in the United States $[60,61]$. Treatment with metoprolol, a betablocker, improved sarcomeric organization in hiPSCCMs, reflecting the improvement in prognosis seen in dilated cardiomyopathy patients treated with this drug [62]. We also created hiPSC-CMs from a patient cohort with familial hypertrophic cardiomyopathy harboring a mutation in the MYH7 gene encoding myosin heavy chain 7, another critical component of the sarcomeric complex [53]. These hiPSC-CMs exhibit enlarged cell size reminiscent of the in vivo hypertrophic cardiomyocyte phenotype [63]. The intracellular calcium ion level was elevated and the cells were associated with irregular calcium transients. These phenotypes were abrogated by treatment with the L-type calcium channel blocker verapamil, which also reduces myocyte hypertrophy in vivo.

A more recent study has focused on hiPSC-CMs derived from patients with arrhythmogenic right ventricular dysplasia/cardiomyopathy (ARVD/C), a disease characterized by fibro-fatty infiltration and replacement of the right ventricular wall myocardium [32]. This patient cohort exhibited a mutation in the PKP2 gene, which encodes plakophilin-2, a component of the desmosome cell-cell adhesion complex. Previous studies have shown that the cardiomyocyte desmosome is mutated in patients with ARVD/C [64]. Patient hiPSC-CMs exhibited reduced expression of plakophilin-2, an increase in intracellular lipid levels, and disorganized sarcomeric structure. Treatment with isoproterenol was able to upregulate hiPSC-CM contractility. Thus, as is the case with the channelopathies, it appears as though hiPSC-CMs can reproduce cellular disease phenotypes associated with cardiomyopathies caused by mutations in sarcomeric and cell adhesion molecules.

\section{Conclusions and future perspectives}

In the past few years we have witnessed an explosion in the number of studies involving patient-specific hiPSCs. hiPSC-CMs derived from cardiovascular disease patients have been shown to recapitulate disease phenotypes and to validate the therapeutic efficacy of candidate drugs in vitro. In particular, drugs that are clinically known to restore proper intracellular ion trafficking and current flow, such as the potassium channel regulator pinacidil and the calcium channel blocker nifedipine, have been shown to suppress irregular action potential in diseasespecific hiPSC-CMs. However, in addition to the aforementioned concerns about hiPSC-CM maturity and purity, other questions regarding hiPSC-CM technology remain to be answered. For example, can hiPSC-CMs be mass-produced in a consistent enough way using high efficiency differentiation methods so that they can be used towards screening hundreds, and perhaps thousands, of drugs for potential cardiotoxicity [65]? Second, if a novel therapeutic agent is successful at restoring proper cardiomyocyte function at a cellular level in the dish, to what extent will its effect be able to translate to the patient? Finally, can the problem of inter-line genetic and epigenetic variability, which exists even among hiPSCs lines from the same individual, be minimized?

In light of these issues, we should remember that iPSC science is only 7 years old. While improvements in hiPSC$\mathrm{CM}$ production, maturation, and purification will continue, there is likely to be a dramatic rise in the utility of these cells for cardiovascular disease modeling in vitro and for high throughput drug screening and discovery. Thus, while still in its infancy, hiPSC-CM technology shines brightly given its potential for clinical applications to improve cardiovascular health in the future.

\section{Note: This article is part of a thematic series on Cardiovascular regeneration edited by Ronald Li. Other articles in the series can be found online at http://stemcellres.com/series/cardiovascular}

\section{Abbreviations}

ARVD/C: Arrhythmogenic right ventricular dysplasia/cardiomyopathy; ESC: Embryonic stem cell; ESC-CM: Embryonic stem cell-derived cardiomyocyte; hESC: Human embryonic stem cell; hiPSC: Human induced pluripotent stem cell; iPSC: Induced pluripotent stem cell; iPSC-CM: Induced pluripotent stem cell-derived cardiomyocyte; MAPK: Mitogen-activated protein kinase; OKSM: Oct4, Klf4, Sox2, c-Myc.

\section{Competing interests}

The authors declare that they have no competing interests.

\section{Acknowledgments}

This work is supported by NIH/NHLBI (U01 HL099776-05), NIH Director's New Innovator's Award (DP2 OD004411-02), and the California Institute for Regenerative Medicine Basic Biology III Award (RB3-05129) (to SMW and JCW).

\section{Author details}

'Department of Biology, Stanford University, Stanford, CA 94305, USA. ${ }^{2}$ Cardiovascular Institute, Stanford University School of Medicine, Stanford, CA 94305, USA. ${ }^{3}$ Division of Cardiovascular Medicine, Department of Medicine, Stanford University School of Medicine, Stanford, CA 94305, USA.

${ }^{4}$ Department of Radiology, Stanford University School of Medicine, Stanford, CA 94305, USA.

Published: 24 Dec 2013 


\section{References}

1. Takahashi K, Yamanaka S: Induction of pluripotent stem cells from mouse embryonic and adult fibroblast cultures by defined factors. Cell 2006, 126:663-676.

2. Chou BK, Mali P, Huang X, Ye Z, Dowey SN, Resar LM, Zou C, Zhang YA, Tong J, Cheng L: Efficient human iPS cell derivation by a non-integrating plasmid from blood cells with unique epigenetic and gene expression signatures. Cell Res 2011, 21:518-529.

3. Zhou T, Benda C, Dunzinger S, Huang Y, Ho JC, Yang J, Wang Y, Zhang Y, Zhuang Q, Li Y, Bao X, Tse HF, Grillari J, Grillari-Voglauer R, Pei D, Esteban MA: Generation of human induced pluripotent stem cells from urine samples. Nat Protoc 2012, 7:2080-2089.

4. Novak A, Shtrichman R, Germanguz I, Segev H, Zeevi-Levin N, Fishman B, Mandel YE, Barad L, Domev H, Kotton D, Mostoslavsky G, Binah O, ItskovitzEldor J: Enhanced reprogramming and cardiac differentiation of human keratinocytes derived from plucked hair follicles, using a single excisable lentivirus. Cell Reprogram 2010, 12:665-678.

5. Fusaki N, Ban H, Nishiyama A, Saeki K, Hasegawa M: Efficient induction of transgene-free human pluripotent stem cells using a vector based on sendai virus, an RNA virus that does not integrate into the host genome. Proc Jpn Acad Ser B Phys Biol Sci 2009, 85:348-362.

6. Jia F, Wilson KD, Sun N, Gupta DM, Huang M, Li Z, Panetta NJ, Chen ZY, Robbins RC, Kay MA, Longaker MT, Wu JC: A nonviral minicircle vector for deriving human iPS cells. Nat Methods 2010, 7:197-199.

7. Rao M: Public private partnerships: a marriage of necessity. Cell Stem Cell 2013, 12:149-151.

8. Dolmetsch $\mathrm{R}$, Geschwind DH: The human brain in a dish: the promise of iPSC-derived neurons. Cell 2011, 145:831-834.

9. Dias J, Gumenyuk M, Kang H, Vodyanik M, Yu J, Thomson JA, Slukvin II: Generation of red blood cells from human induced pluripotent stem cells. Stem Cells Dev 2011, 20:1639-1647.

10. Burridge PW, Thompson S, Millrod MA, Weinberg S, Yuan X, Peters A, Mahairaki V, Koliatsos VE, Tung L, Zambidis ET: A universal system for highly efficient cardiac differentiation of human induced pluripotent stem cells that eliminates interline variability. PlOS ONE 2011, 6:e18293.

11. Go AS, Mozaffarian D, Roger VL, Benjamin EJ, Berry JD, Borden WB, Bravata DM, Dai S, Ford ES, Fox CS, Franco S, Fullerton HJ, Gillespie C, Hailpern SM, Heit JA, Howard VJ, Huffman MD, Kissela BM, Kittner SJ, Lackland DT, Lichtman JH, Lisabeth LD, Magid D, Marcus GM, Marelli A, Matchar DB, McGuire DK, Mohler ER, Moy CS, Mussolino ME, et al: Heart disease and stroke statistics - 2013 update: a report from the American Heart Association. Circulation 2013, 127:e6-e245.

12. Laflamme MA, Murry CE: Heart regeneration. Nature 2011, 473:326-335.

13. Bergmann O, Bhardwaj RD, Bernard S, Zdunek S, Barnabe-Heider F, Walsh S, Zupicich J, Alkass K, Buchholz BA, Druid H, Jovinge S, Frisen J: Evidence for cardiomyocyte renewal in humans. Science 2009, 324:98-102.

14. Dean RG, Balding LC, Candido R, Burns WC, Cao Z, Twigg SM, Burrell LM: Connective tissue growth factor and cardiac fibrosis after myocardial infarction. J Histochem Cytochem 2005, 53:1245-1256.

15. Bigger JT Jr, Fleiss JL, Kleiger R, Miller JP, Rolnitzky LM: The relationships among ventricular arrhythmias, left ventricular dysfunction, and mortality in the 2 years after myocardial infarction. Circulation 1984, 69:250-258.

16. von Gise A, Lin Z, Schlegelmilch K, Honor LB, Pan GM, Buck JN, Ma Q, Ishiwata T, Zhou B, Camargo FD, Pu WT: YAP1, the nuclear target of Hippo signaling, stimulates heart growth through cardiomyocyte proliferation but not hypertrophy. Proc Natl Acad Sci U S A 2012, 109:2394-2399.

17. Bersell $K$, Arab S, Haring B, Kuhn B: Neuregulin $1 /$ ErbB4 signaling induces cardiomyocyte proliferation and repair of heart injury. Cell 2009, 138:257-270.

18. Beltrami AP, Barlucchi L, Torella D, Baker M, Limana F, Chimenti S, Kasahara H, Rota M, Musso E, Urbanek K, Leri A, Kajstura J, Nadal-Ginard B, Anversa P: Adult cardiac stem cells are multipotent and support myocardial regeneration. Cell 2003, 114:763-776.

19. Kehat I, Kenyagin-Karsenti D, Snir M, Segev H, Amit M, Gepstein A, Livne E, Binah O, Itskovitz-Eldor J, Gepstein L: Human embryonic stem cells can differentiate into myocytes with structural and functional properties of cardiomyocytes. J Clin Invest 2001, 108:407-414.

20. Kattman SJ, Witty AD, Gagliardi M, Dubois NC, Niapour M, Hotta A, Ellis Keller G: Stage-specific optimization of activin/nodal and BMP signaling promotes cardiac differentiation of mouse and human pluripotent stem cell lines. Cell Stem Cell 2011, 8:228-240.
21. Yang Y, Min JY, Rana JS, Ke Q, Cai J, Chen Y, Morgan JP, Xiao YF: VEGF enhances functional improvement of postinfarcted hearts by transplantation of ESC-differentiated cells. J Appl Physiol 2002, 93:1 140-1151.

22. Klug MG, Soonpaa MH, Koh GY, Field LJ: Genetically selected cardiomyocytes from differentiating embronic stem cells form stable intracardiac grafts. J Clin Invest 1996, 98:216-224.

23. Fairchild PJ: The challenge of immunogenicity in the quest for induced pluripotency. Nat Rev Immunol 2010, 10:868-875.

24. Zhao T, Zhang ZN, Rong Z, Xu Y: Immunogenicity of induced pluripotent stem cells. Nature 2011, 474:212-215.

25. Araki R, Uda M, Hoki Y, Sunayama M, Nakamura M, Ando S, Sugiura M, Ideno H, Shimada A, Nifuji A, Abe M: Negligible immunogenicity of terminally differentiated cells derived from induced pluripotent or embryonic stem cells. Nature 2013, 494:100-104.

26. Guha P, Morgan JW, Mostoslavsky G, Rodrigues NP, Boyd AS: Lack of immune response to differentiated cells derived from syngeneic induced pluripotent stem cells. Cell Stem Cell 2013, 12:407-412.

27. Lian X, Hsiao C, Wilson G, Zhu K, Hazeltine LB, Azarin SM, Raval KK, Zhang J, Kamp TJ, Palecek SP: Robust cardiomyocyte differentiation from human pluripotent stem cells via temporal modulation of canonical Wnt signaling. Proc Natl Acad Sci U S A 2012, 109:E1848-E1857.

28. Carvajal-Vergara X, Sevilla A, D'Souza SL, Ang YS, Schaniel C, Lee DF, Yang L, Kaplan AD, Adler ED, Rozov R, Ge Y, Cohen N, Edelmann LJ, Chang B, Waghray A, Su J, Pardo S, Lichtenbelt KD, Tartaglia M, Gelb BD, Lemischka IR: Patient-specific induced pluripotent stem-cell-derived models of LEOPARD syndrome. Nature 2010, 465:808-812.

29. Ma J, Guo L, Fiene SJ, Anson BD, Thomson JA, Kamp TJ, Kolaja KL, Swanson $B J$, January CT: High purity human-induced pluripotent stem cell-derived cardiomyocytes: electrophysiological properties of action potentials and ionic currents. Am J Physiol Heart Circ Physiol 2011, 301:H2006-H2017.

30. Hoekstra M, Mummery CL, Wilde AA, Bezzina CR, Verkerk AO: Induced pluripotent stem cell derived cardiomyocytes as models for cardiac arrhythmias. Front Physiol 2012, 3:346.

31. Gherghiceanu M, Barad L, Novak A, Reiter I, Itskovitz-Eldor J, Binah O, Popescu LM: Cardiomyocytes derived from human embryonic and induced pluripotent stem cells: comparative ultrastructure. J Cell Mol Med 2011, 15:2539-2551.

32. Novak A, Barad L, Zeevi-Levin N, Shick R, Shtrichman R, Lorber A, ItskovitzEldor J, Binah O: Cardiomyocytes generated from CPVTD307H patients are arrhythmogenic in response to beta-adrenergic stimulation. J Cell Mol Med 2012, 16:468-482.

33. Moretti $A$, Bellin $M$, Welling $A$, Jung $C B$, Lam JT, Bott-Flugel $L$, Dorn $T$, Goedel A, Hohnke C, Hofmann F, Seyfarth M, Sinnecker D, Schomig A, Laugwitz KL: Patient-specific induced pluripotent stem-cell models for long-QT syndrome. N Engl J Med 2010, 363:1397-1409.

34. Kubalak SW, Miller-Hance WC, O'Brien TX, Dyson E, Chien KR: Chamber specification of atrial myosin light chain-2 expression precedes septation during murine cardiogenesis. J Biol Chem 1994, 269:16961-16970.

35. Franco D, Markman MM, Wagenaar GT, Ya J, Lamers WH, Moorman AF: Myosin light chain 2a and $2 v$ identifies the embryonic outflow tract myocardium in the developing rodent heart. Anat Rec 1999, 254:135-146.

36. Fu JD, Jiang P, Rushing S, Liu J, Chiamvimonvat N, Li RA: Na+/Ca2+ exchanger is a determinant of excitation-contraction coupling in human embryonic stem cell-derived ventricular cardiomyocytes. Stem Cells Dev 2010, 19:773-782.

37. Dubois NC, Craft AM, Sharma P, Elliott DA, Stanley EG, Elefanty AG, Gramolini A, Keller G: SIRPA is a specific cell-surface marker for isolating cardiomyocytes derived from human pluripotent stem cells. Nat Biotechnol 2011, 29:1011-1018.

38. Ye L, Zhang S, Greder L, Dutton J, Keirstead SA, Lepley M, Zhang L, Kaufman $D$, Zhang J: Effective cardiac myocyte differentiation of human induced pluripotent stem cells requires VEGF. PlOS ONE 2013, 8:e53764.

39. Gutierrez-Aranda I, Ramos-Mejia V, Bueno C, Munoz-Lopez M, Real PJ, Macia A, Sanchez L, Ligero G, Garcia-Parez JL, Menendez P: Human induced pluripotent stem cells develop teratoma more efficiently and faster than human embryonic stem cells regardless the site of injection. Stem Cells 2010, 28:1568-1570.

40. Egashira T, Yuasa S, Suzuki T, Aizawa Y, Yamakawa H, Matsuhashi T, Ohno Y, Tohyama S, Okata S, Seki T, Kuroda Y, Yae K, Hashimoto H, Tanaka T, Hattori F, Sato T, Miyoshi S, Takatsuki S, Murata M, Kurokawa J, Furukawa T, Makita N, Aiba T, Shimizu W, Horie M, Kamiya K, Kodama I, Ogawa S, Fukuda K: 
Disease characterization using LQTS-specific induced pluripotent stem cells. Cardiovasc Res 2012, 95:419-429.

41. Itzhaki I, Maizels L, Huber I, Zwi-Dantsis L, Caspi O, Winterstern A, Feldman O, Gepstein A, Arbel G, Hammerman H, Boulos M, Gepstein L: Modelling the long QT syndrome with induced pluripotent stem cells. Nature 2011 471:225-229.

42. Matsa E, Rajamohan D, Dick E, Young L, Mellor I, Staniforth A, Denning C: Drug evaluation in cardiomyocytes derived from human induced pluripotent stem cells carrying a long QT syndrome type 2 mutation. Eur Heart J 2011, 32:952-962.

43. Lahti AL, Kujala VJ, Chapman H, Koivisto AP, Pekkanen-Mattila M, Kerkela E, Hyttinen J, Kontula K, Swan H, Conklin BR, Yamanaka S, Silvennoinen O, Aalto-Setala K: Model for long QT syndrome type 2 using human iPS cells demonstrates arrhythmogenic characteristics in cell culture. Dis Model Mech 2012, 5:220-230.

44. Malan D, Friedrichs S, Fleischmann BK, Sasse P: Cardiomyocytes obtained from induced pluripotent stem cells with long-QT syndrome 3 recapitulate typical disease-specific features in vitro. Circ Res 2011, 109:841-847.

45. Davis RP, Casini S, van den Berg CW, Hoekstra M, Remme CA, Dambrot C, Salvatori D, Oostwaard DW, Wilde AA, Bezzina CR, Verkerk AO, Freund C, Mummery CL: Cardiomyocytes derived from pluripotent stem cells recapitulate electrophysiological characteristics of an overlap syndrome of cardiac sodium channel disease. Circulation 2012, 125:3079-3091.

46. Terrenoire C, Wang K, Tung KW, Chung WK, Pass RH, Lu JT, Jean JC, Omari A, Sampson KJ, Kotton DN, Keller G, Kass RS: Induced pluripotent stem cells used to reveal drug actions in a long QT syndrome family with complex genetics. J Gen Physiol 2013, 141:61-72.

47. Yazawa M, Hsueh B, Jia X, Pasca AM, Bernstein JA, Hallmayer J, Dolmetsch RE: Using induced pluripotent stem cells to investigate cardiac phenotypes in Timothy syndrome. Nature 2011, 471:230-234.

48. Jung CB, Moretti A, Mederos y Schnitzler M, Lop L, Storch U, Bellin M, Dorn T, Ruppenthal S, Pfeiffer S, Goedel A, Dirschinger RJ, Seyfarth M, Lam JT, Sinnecker D, Gudermann T, Lipp P, Laugwitz KL: Dantrolene rescues arrhythmogenic RYR2 defect in a patient-specific stem cell model of catecholaminergic polymorphic ventricular tachycardia. EMBO Mol Med 2012, 4:180-191.

49. Fatima A, Xu G, Shao K, Papadopoulos S, Lehmann M, Arnaiz-Cot JJ, Rosa AO, Nguemo F, Matzkies M, Dittmann S, Stone SL, Linke M, Zechner U, Beyer V, Hennies HC, Rosenkranz S, Klauke B, Parwani AS, Haverkamp W, Pfitzer G, Farr M, Cleemann L, Morad M, Milting H, Hescheler J, Saric T: In vitro modeling of ryanodine receptor 2 dysfunction using human induced pluripotent stem cells. Cell Physiol Biochem 2011, 28:579-592.

50. Kujala K, Paavola J, Lahti A, Larsson K, Pekkanen-Mattila M, Viitasalo M, Lahtinen AM, Toivonen L, Kontula K, Swan H, Laine M, Silvennoinen O, Aalto-Setala K: Cell model of catecholaminergic polymorphic ventricular tachycardia reveals early and delayed afterdepolarizations. PlOS ONE 2012, 7:e44660.

51. Itzhaki I, Maizels L, Huber I, Gepstein A, Arbel G, Caspi O, Miller L, Belhassen B, Nof E, Glikson M, Gepstein L: Modeling of catecholaminergic polymorphic ventricular tachycardia with patient-specific humaninduced pluripotent stem cells. J Am College Cardiol 2012, 60:990-1000.

52. Sun N, Yazawa M, Liu J, Han L, Sanchez-Freire V, Abilez OJ, Navarrete EG, Hu S, Wang L, Lee A, Pavlovic A, Lin S, Chen R, Hajjar RJ, Snyder MP, Dolmetsch RE, Butte MJ, Ashley EA, Longaker MT, Robbins RC, Wu JC: Patient-specific induced pluripotent stem cells as a model for familial dilated cardiomyopathy. Sci Trans/ Med 2012, 4:130ra147.

53. Lan F, Lee AS, Liang P, Sanchez-Freire V, Nguyen PK, Wang L, Han L, Yen M, Wang $Y$, Sun N, Abilez OJ, Hu S, Ebert AD, Navarrete EG, Simmons CS, Wheeler M, Pruitt B, Lewis R, Yamaguchi Y, Ashley EA, Bers DM, Robbins RC, Longaker MT, Wu JC: Abnormal calcium handling properties underlie familial hypertrophic cardiomyopathy pathology in patient-specific induced pluripotent stem cells. Cell Stem Cell 2013, 12:101-113.

54. Ma D, Wei H, Lu J, Ho S, Zhang G, Sun X, Oh Y, Tan SH, Ng ML, Shim W, Wong P, Liew R: Generation of patient-specific induced pluripotent stem cell-derived cardiomyocytes as a cellular model of arrhythmogenic right ventricular cardiomyopathy. Eur Heart J 2013, 34:1122-1133.

55. Kim C, Wong J, Wen J, Wang S, Wang C, Spiering S, Kan NG, Forcales S, Puri PL, Leone TC, Marine JE, Calkins H, Kelly DP, Judge DP, Chen HS: Studying arrhythmogenic right ventricular dysplasia with patient-specific iPSCs. Nature 2013, 494:105-110.
56. Huang HP, Chen PH, Hwu WL, Chuang CY, Chien YH, Stone L, Chien CL, Li LT, Chiang SC, Chen HF, Ho HN, Chen CH, Kuo HC: Human Pompe diseaseinduced pluripotent stem cells for pathogenesis modeling, drug testing and disease marker identification. Hum Mol Genet 2011, 20:4851-4864.

57. Marban E: Cardiac channelopathies. Nature 2002, 415:213-218.

58. Splawski I, Timothy KW, Sharpe LM, Decher N, Kumar P, Bloise R, Napolitano C, Schwartz PJ, Joseph RM, Condouris K, Tager-Flusberg H, Priori SG, Sanguinetti MC, Keating MT: $\mathrm{Ca}(\mathrm{V}) 1.2$ calcium channel dysfunction causes a multisystem disorder including arrhythmia and autism. Cell 2004, 119:19-31.

59. Priori SG, Napolitano C, Tiso N, Memmi M, Vignati G, Bloise R, Sorrentino V, Danieli GA: Mutations in the cardiac ryanodine receptor gene (hRyR2) underlie catecholaminergic polymorphic ventricular tachycardia. Circulation 2001, 103:196-200.

60. Roura S, Bayes-Genis A: Vascular dysfunction in idiopathic dilated cardiomyopathy. Nat Rev Cardiol 2009, 6:590-598.

61. Harmon WE, McDonald RA, Reyes JD, Bridges ND, Sweet SC, Sommers CM Guidinger MK: Pediatric transplantation, 1994-2003. Am J Transp/ 2005, 5:887-903.

62. Engelmeier RS, O'Connell JB, Walsh R, Rad N, Scanlon PJ, Gunnar RM: Improvement in symptoms and exercise tolerance by metoprolol in patients with dilated cardiomyopathy: a double-blind, randomized, placebo-controlled trial. Circulation 1985, 72:536-546.

63. Geisterfer-Lowrance AA, Kass S, Tanigawa G, Vosberg HP, McKenna W, Seidman CE, Seidman JG: A molecular basis for familial hypertrophic cardiomyopathy: a beta cardiac myosin heavy chain gene missense mutation. Cell 1990, 62:999-1006.

64. Yang Z, Bowles NE, Scherer SE, Taylor MD, Kearney DL, Ge S, Nadvoretskiy W, DeFreitas G, Carabello B, Brandon LI, Godsel LM, Green KJ, Saffitz JE, Li H, Danieli GA, Calkins H, Marcus F, Towbin JA: Desmosomal dysfunction due to mutations in desmoplakin causes arrhythmogenic right ventricular dysplasia/cardiomyopathy. Circ Res 2006, 99:646-655.

65. Force T, Kolaja KL: Cardiotoxicity of kinase inhibitors: the prediction and translation of preclinical models to clinical outcomes. Nat Rev Drug Discov 2011, 10:111-126.

66. Pandit B, Sarkozy A, Pennacchio LA, Carta C, Oishi K, Martinelli S, Pogna EA, Schackwitz W, Ustaszewska A, Landstrom A, Bos JM, Ommen SR, Esposito G, Lepri F, Faul C, Mundel P, Lopez Siguero JP, Tenconi R, Selicorni A, Rossi C, Mazzanti L, Torrente I, Marino B, Digilio MC, Zampino G, Ackerman MJ, Dallapiccola B, Tartaglia M, Gelb BD: Gain-of-function RAF1 mutations cause Noonan and LEOPARD syndromes with hypertrophic cardiomyopathy. Nat Genet 2007, 39:1007-1012.

67. Feinleib M, Garrison RJ, Fabsitz R, Christian JC, Hrubec Z, Borhani NO, Kannel WB, Rosenman R, Schwartz JT, Wagner JO: The NHLBI twin study of cardiovascular disease risk factors: methodology and summary of results. Am J Epidemiol 1977, 106:284-285.

$10.1186 /$ scrt380

Cite this article as: Sharma et al:: Induced pluripotent stem cell-derived cardiomyocytes for cardiovascular disease modeling and drug screening. Stem Cell Research \& Therapy 2013, 4:150 